\title{
Against the Rising Tide of Crime: Cesare Lombroso and Control of the "Dangerous Classes" in Italy, 1861-1940
}

Emilia Musumeci

\section{(2) OpenEdition Journals}

Electronic version

URL: http://journals.openedition.org/chs/2313

DOI: $10.4000 /$ chs.2313

ISSN: 1663-4837

\section{Publisher}

Librairie Droz

\section{Printed version}

Date of publication: 31 December 2018

Number of pages: 83-106

ISSN: $1422-0857$

\section{Electronic reference}

Emilia Musumeci, "Against the Rising Tide of Crime: Cesare Lombroso and Control of the "Dangerous Classes" in Italy, 1861-1940", Crime, Histoire \& Sociétés / Crime, History \& Societies [Online], vol. 22, n² I 2018, Online since 31 December 2020, connection on 13 April 2021. URL: http:// journals.openedition.org/chs/2313; DOI: https://doi.org/10.4000/chs.2313

This text was automatically generated on 13 April 2021.

(c) Droz 


\title{
Against the Rising Tide of Crime: Cesare Lombroso and Control of the "Dangerous Classes" in Italy, 1861-1940
}

\author{
Emilia Musumeci
}

\section{Introduction: "like a natural disaster"}

1 In 1879, shortly after the publication of the first edition of his well-known and provocative book, L'uomo delinquente [published in English as Criminal Man (1911)], ${ }^{1}$ Cesare Lombroso, in his "minor" work entitled Sull'incremento del delitto in Italia e dei mezzi per arrestarlo [On the Increase of Crime in Italy and the Means to Stop it] warned readers that: "the tide of crime is increasingly rising, and threatens to submerge civilisation, if no one thinks about building a dam to stop it". ${ }^{2}$ The battle against crime seemed to Lombroso's eyes unfair if fought without the necessary tools, like a defenceless man in the face of a natural disaster. Lombroso's opinion was, however, not an isolated one: after the unification of Italy in 1861, there had followed a period of emergency stemming from gradual but inexorable migration from the countryside to the cities, which became increasingly crowded with social outcasts that would populate the ranks of what would become known as the "dangerous classes". ${ }^{3}$ This term came to refer to the great multitude of robbers, prostitutes, "subversives" and other common inhabitants of inner-city areas that, thanks to a certain literary imagery, became places of perdition and immorality. ${ }^{4}$

2 Among these marginal individuals, depicted in literature and chronicles of the time with increasingly fearsome traits, sometimes almost resembling wild beasts, prostitutes certainly occupied a prominent place. $^{5}$ These classes were seen to consisted of a multitude of criminals and outlaws ranging from "the idler and the gambler to the thief and the murderer, from the cutpurse and from the camorrist to the associations and 
gangs of criminals, from the lost woman corrupted by the elegant world to the prostitute of the lowest classes". ${ }^{6}$ In this sense, the exacerbation of the image of the prostitute as an enemy of society, in fact, is part of a greater question concerning the protection of public order, the emerging but increasingly burning issue of the protection of public health, heavily threatened by mercenary love and the consequent risk of contagion from venereal diseases such as syphilis of which prostitutes were considered almost automatically as "natural" carriers. ${ }^{7}$ Not surprisingly, the era of regulated prostitution would soon begin in Italy ${ }^{8}$ with the supervision of this phenomenon under the jurisdiction of the police, along with control of vagabondage, ${ }^{9}$ as already happened in France ${ }^{10}$ and other European countries. ${ }^{11}$

3 In addition to the problem of control of the "dangerous classes", there was a question that blended with the dynamics of national-identity-building: the phenomenon of brigandage. ${ }^{12}$ In contrast to the new threat of "urban crime", brigands still resisted in the countryside of the South of the new-born Kingdom of Italy. The almost legendary figure of the brigand became the enemy of national unification, ${ }^{13}$ a negative hero par excellence, like the brigand Gramigna, ${ }^{14}$ described by the writer Giovanni Verga as a cursed and scary figure at the time of his capture when "he was foaming at the mouth [with] eyes [...] shining like those of a wolf". ${ }^{15}$

4 The new kingdom of Italy was consequently born with the symptoms of a state of emergency: it was perceived necessary to stem this dangerous flow of crime to build the new Italian nation successfully. ${ }^{16}$ To do this required the identification, control and, if possible, neutralization of reputed criminals. This article will illustrate the attempted creation of new techniques, based on the teachings of Cesare Lombroso, in order to control the so-called "dangerous classes" in Italy between the end of the nineteenth century and the mid-twentieth century. The article will focus in particular on analysis of the legacy of Lombrosian criminal anthropology in a field still subject to limited attention on the part of historians, namely that of its impact on policing and the administration of justice. After briefly outlining the salient characteristics of Lombrosian theories and his "science of crime", the article will focus on the efforts to create a scientific police and a new method of identifying the delinquent to supplant the Bertillonage System. ${ }^{17}$ Despite the development of similar identification techniques in many countries,$^{18}$ the Italian context is quite different, being strongly influenced not only by the need for "modern instruments to fight crime" but above all by Lombroso's teaching and ambition: "the transformation of policing into a scientific instrument". ${ }^{19}$ This was the birth of the so-called "Ottolenghi method", acclaimed abroad and sadly used, especially during the Fascist regime, to identify not only criminals but also subversives, enemies of social order and any suspicious individuals.

5 The originality of this article, therefore, lies in its focus on a little-known area of Lombrosian studies, namely the history of criminal identification techniques in Italy. Moreover, new light is shed on the legacy of criminal anthropology in policing and criminal justice in the delicate transition from liberal Italy to the Fascist regime. Unlike the traditional approach, according to which the authoritarian traits in Fascist legislation derived from Lombroso's theories, ${ }^{20}$ in this article, through a new and extensive analysis of the "real" content of Lombrosian theses, we will seek to demonstrate that criminal anthropology did not itself influence the repressive character of the fascist police and the related justice system. On the contrary, the ideas of Lombroso and his School under the regime were distorted and exploited to become a 
powerful weapon of the dictatorship for recording and controlling their political enemies. The research behind this intervention, therefore, hopes to bring distinctive insights that will further our overall understanding of the legacy of Cesare Lombroso or rather "the most significant, if also the most puzzling and contradictory, figure in the entire history of criminology". ${ }^{21}$

\section{Science and crime}

During his long career Lombroso attempted to identify, record and control the new, dangerous, disruptive criminals of an already precarious social and political order. $\mathrm{He}$ began "scientifically" to certify differences, not only among criminals and "normal" individuals, ${ }^{22}$ but also among different types of offenders, ${ }^{23}$ in the belief that the physical reflects moral "monstrosity". ${ }^{24}$ Lombroso's investigation, striving to discover what a great monstrum lurks behind the simple thief or brigand, should be considered in this context. In this sense Lombroso embarked on a frantic search over the bodies and faces of prisoners and lunatics, in order to find the stigmata of deviance, the unmistakeable, irrefutable evidence that a criminal is predetermined to commit evil acts because he is biologically different from any other human being.

The most emblematic example of this attitude is provided by the famous and contested "discovery" 25 attributed to Lombroso, that of the median occipital fossa in the skull of Giuseppe Villella, a seventy year old brigand from Calabria who died in prison under suspicion of robbery. Thanks to this discovery, Lombroso theorized the differences between criminals and the so-called "normal" individuals, asserting that a criminal is, from birth, an "unhappy variety of human which is, in my opinion, more pathological than the lunatic". ${ }^{26}$ According to Lombroso, this was the evidence that in criminals there are frequent monstrous regressions that correspond to characteristics observed in the skulls of the "lower level of the rodent or lemur, or the brain of a human fetus [sic] of three or four months". ${ }^{27}$ Thus the theory of the "born criminal" was itself born.

8 In 1870, during a "cold, grey November morning" (as his daughter, Gina Lombroso, wrote), ${ }^{28}$ while he was examining the skull, Lombroso found a strange anomaly: on the occipital part, where a spine would normally be found on a human skull, there was, instead, a distinct anomaly that he called the median occipital fossetta. ${ }^{29}$ This anatomical peculiarity, which Lombroso described as the "birth certificate" anthropology, explained the existence of crime through atavism ${ }^{31}$ (from Latin atavus, or ancestor), coinciding with the return to an ancestral and lower stage of evolution, and becoming the emblem of a new legislative framework designed as a real science of the abnormal. The "discovery" of the fossetta, was described by Lombroso only thirty-five years later, in his opening address to the Sixth International Congress of Criminal Anthropology. In this way, whatever the intentions of Lombroso, now the myth of Villella's skull had been consecrated forever..$^{32}$ Not surprisingly, Villella's skull became, as Lombroso emphatically admitted, a sort of "fetish or totem of criminal anthropology", inaugurating his frantic search for the biological origins of crime. ${ }^{33}$

9 After that of Villella's skull, a second revelation helped Lombroso develop his theories about the origins of crime. The "most direct proof of atavism" was, some years later, the case of a twenty-two-year-old man from Bergamo in northern Italy, Vincenzo Verzeni, who was "what in the language of modern journalism is called a monster". ${ }^{34}$ Also known in the records of the times as "the Strangler of Women" 35 or "the Vampire 
of Padania", ${ }^{36}$ Verzeni's can be considered the first Italian case of a sexual serial killer. His case was so dramatic that it aroused media attention almost in the same way as show trials do today, and he is still considered as one of the bloodiest serial killers in history, having derived sexual pleasure from the act of murder by strangulation and from drinking blood and eating the intestines of his victims ${ }^{37}$ Faced with such ferocity which, it was considered, could not merely be explained by madness or other mental disorders, Lombroso resolved the case by applying the controversial nosological concept of "moral insanity". In this way - Lombroso argued - the atavistic theory of crime was completed and corrected: in short, "to cerebral malnutrition and to poor nerve conduction is added the disease of monstrosity". ${ }^{38}$

Hence, not only are charges of Lombroso's criminalization of the Southern people unfounded, but it is also a simplistic reading of Lombroso's theories to excessively reduce his work solely to an attempt to identify criminals through their external features or atavism. In reality, the "criminal man" imagined by Lombroso was more complex and multifaceted than a "primitive man" or a sort of walking museum piece. Indeed, considering the overall articulation of Lombroso's work, it is understandable that atavism constituted a milestone in his research, but (as indicated by Paul Knepper elsewhere in this special issue) it was not the ultimate solution to the ambitious question about the origins of crime. In particular, atavism especially influenced only the first edition of Criminal Man, which was modified and amended many times before Lombroso's death. In particular, as showed by the analysis of the different editions of the book, Lombroso gradually refined his theories on the explanation of crime, according to clinical case studies that range from the initial thesis of the born criminal as a savage, to the theory of the political criminal as mattoid (an ambivalent kind of deviance between genius and insanity), and that of "occasional criminals", defined criminaloids. $^{39}$

\section{Looking for identity: inside the criminal world}

In addition to biological factors of criminality Lombroso posited that the dichotomy between "normal" people and criminals would necessarily be reflected in offenders' external manifestations. Contrary to popular opinion, Lombrosian research focused not only on criminals' faces or their cranial shapes, but on all physical and psychological characteristics, including their verbal (slang) and non-verbal (tattoos) manifestations, and even their artefacts: the whole "criminal world".

In short, criminality in itself was depicted as a sort of "pathology". Believing that even the criminal's language had to be insane, Lombroso began to study all forms of lexicon used by prisoners, from the written to the spoken. For this purpose, he sought every form of expression used in the Italian prisons into which he went almost daily. However, prison conditions were poor at the time, and the rights of inmates were practically non-existent. For example, in order to avoid any risk of communication, convicts were not allowed to have pieces of paper on which to write. Prisoners were thus forced to use any means available to express their thoughts during their long periods of detention. For instance, they left to posterity their sentences, proclamations, poems, or even merely their signatures, by scraping away the enamel from drinking jars, or engraving on their cell walls or the wood of their beds. Lombroso diligently 
analysed these expressions, publishing his results in Palimsesti del Carcere [Prison Palimpsests]. ${ }^{40}$

Despite being considered a minor work, it was one of the first attempts in the history of criminology to study the cultural aspects of prison life. ${ }^{41}$ In this book, Lombroso subverted an old belief "that the prison, and especially the cell, is a sort of dumb and paralytic organism or a body without tongue and hands, only because the law had forced it to remain silent and motionless". ${ }^{42}$ From his analysis of the prisoners' writings came a psychological framing of the "criminal type": egocentric, detached from others, vain, vengeful, and deceptively religious. These characteristics led Lombroso to conclude not only that "criminals cannot speak the same language [as] honest men", but also that criminals "speak differently because they feel differently". ${ }^{43}$ This was apparent, according to Lombroso, in the recurring topics (the crime committed, sex, religion, prison, and revenge), as well as in the choice of slang, a previously undocumented secret language (or anti-language) widespread among criminals.

According to Lombroso, the biological signs of criminality were visible and served as real "stigmata", both on the body and produced by the body, betraying the criminal. He found that the "primitive" verbal language of prisoners was accompanied by a more visual language: that of tattoos, introduced by sailors returning from the South Pacific and in vogue, especially among prison populations and prostitutes. Lombroso saw these tattoos ${ }^{44}$ as another element of their criminal communications. ${ }^{45}$ Although tattoos were not exclusive to criminals, according to Lombroso, "tattooing assumes a specific character, a strange tenacity and diffusion among the miserable class of criminals", ${ }^{46}$ among whom the tattoo can be considered, to use the medico-legal term, as a professional characteristic. The habit of tattooing their bodies with images representing symbols of strength or explicit allusions to sex was so common among criminals as to be a special trait among them. In other words, criminals' use of slang and the proclivity to tattoo their bodies were evidence, according to Lombroso, that criminals were radically different from "normal men" because they were atavistic beings with the ferocious instincts of wild beasts. ${ }^{47}$ Criminals, like savages, had "violent passions, a blunted sensibility, puerile vanity, longstanding tendencies towards inaction, and very often nudity". ${ }^{48}$ However, tattooed criminals, or "living parchments" ${ }^{49}$ sometimes surpassed primitive men in their savagery, tattooing even their genitals. ${ }^{50}$ This was evidence not only of their shamelessness, but also of their uncommon insensibility to pain.

Moreover, when Lombroso compared tattoos between criminals and insane people, he concluded that, while the practice of tattooing among lunatics was quite rare, in most cases, tattooed lunatics were morally insane people, differing from criminals by their "insensibility" and "paralysis of moral sense". The imagery of criminals' tattoos was also, according to Lombroso, more violent or obscene in character: grotesque symbols of virile power, images depicting "criminal careers" such as an organised crime affiliation, or pictures of crimes committed, as evident in a photo of a rapist which Lombroso used to illustrate his point, his body totally covered by tattoos symbolising crimes of sexual violence. Other recurring topics included unpleasant, lubricious, and/ or obscene figures, or revenge, as evident in a picture included by Lombroso in the first edition of Criminal Man: a prisoner displaying several tattoos, including snakes, an emblem of Savoy on his penis and crossed daggers surrounded by the motto "I swear to revenge myself" [Giuro di vendicarmi], on his chest. ${ }^{51}$ 
Lombroso and his school was to revolutionise all branches of knowledge: by adding to the body of information in the newly established discipline called "criminal anthropology", the forerunner of modern criminology, he aimed to completely alter every matter having to do with the criminal man: criminal law, forensic medicine, policing, and criminal justice. ${ }^{54}$ His novel conception of penal law, to be based not on free will but on social dangerousness, was accompanied by a new and pressing need: to have "new" police officers, trained according to the dictates of the new Positivistic School. ${ }^{55}$ Even though the nineteenth century was an age of great transformation of police and its multiple ${ }^{56}$ functions in many Western countries, ${ }^{57}$ where the work of Bertillon was highly influential, the history of policing and the science of crime in Italy had an undeniable specificity. ${ }^{58}$

19 The Italian context was strongly affected by the debate on opposed models of criminal law. In particular, the aim of the well-known Italian alienist was to go beyond the rationalistic-illuminist approach of penal $\mathrm{law}^{59}$ and to transform it into a science, ${ }^{60} \mathrm{a}$ legal system no longer based on the overly metaphysical concept of free will and imputability, but on the more practical concept of social dangerousness. ${ }^{61}$ If the goal was to defend young Italy from any possible element that could destabilize its already precarious equilibrium, it was necessary to train "scientific" policemen, based on the directives of the new Positive School, who could thus be empowered to fight crime with the innovative tools of science. Moreover, that the outmoded and disorganized police forces of the pre-unification states (i.e., the gendarmes and birri of the nineteenth century) ${ }^{62}$ were unprepared for the fight against crime was irrefutable. Not by chance, in 1871, the Chief of Police, Giovanni Bolis, stated that the degree of public and private security of Italy - thanks to a redevelopment of its police officers, was "the safest thermometer to judge the good governance of a State". ${ }^{63}$ If Bolis thought an authoritative body of police worthy of the new "tri-colour flag", ${ }^{64}$ Lombroso went even 
further, asserting that the new Kingdom of Italy deserved not only a prestigious, but also a technologically-advanced, police force.

Lombroso coined the term scientific police in 1879 when he first sought this radical transformation: "We must [take] in the police the same step that Sadowa taught us to [...] in the military - make it a scientific [...] force, able to [use] scientific instruments [including] photography, telegraphy, newspapers, and above all [...]knowledge of the criminal man". ${ }^{65}$ It is no coincidence that Lombroso used a military metaphor ${ }^{66}$ to talk about the need to train Italian police officers to the standards of modern English policemen ${ }^{67} \mathrm{His}$ was, in fact, a genuine "call to arms" against those collectively called by many as an "army of crime", advancing dangerously in the increasingly populous cities. $^{68}$

This call was taken up by one of his pupils, Salvatore Ottolenghi, a professor of forensic medicine who, significantly, taught the first course in scientific policing [polizia scientifica] at the University of Siena. In 1902 this teaching was moved to Rome, and in 1907 it was transformed into an official school, the School of Scientific Policing [Scuola di Polizia Scientifica] located close to the New Prisons [Carceri Nuove]. The school consisted of classrooms, as well as forensic laboratories in which to take and examine fingerprints ${ }^{69}$ and criminal photographs, or "mugshots". ${ }^{70}$ The School's location was not casual: its proximity to the prisons enabled its students to easily observe the prisoners as "valuable educational matter". The most important subjects, all geared to the dictates of Cesare Lombroso's criminal anthropology, were the technical use of fingerprints in crime-solving, developed in Italy by Giovanni Gasti, and forensic photography, attributed to Umberto Ellero. ${ }^{71}$ Some years later, in 1910, the official journal of the School (Bollettino della Scuola di Polizia Scientifica) was founded by Ottolenghi. The purpose of the School was therefore to create a new kind of policeman who investigated crimes in a "rational" and scientific way, instead of using "empirical methods", which were often poorly coordinated and based upon random trends. Criminal investigations thus became more objective and effective.

However, the main concern of the time was to find an accurate method to identify criminals, a necessary response to the increasing populations and crime rates in urban areas. Before the adoption of fingerprinting, "anthropometry", invented in France by Alphonse Bertillon, was the dominant form of biometric identification used by law enforcement bodies. This method, also known as the Bertillon system, involved the scientific study of the measurements and proportions of the human body, and consisted of three parts: description, measurement of the criminal body, and classification. It was first used in Italy, promoted by Ottolenghi, but only briefly and minimally. Soon the Bertillon system, deemed expensive, impractical, and not useful in cases of juvenile offenders, was supplanted by the "Italian method". Giovanni Gasti, pupil and collaborator of Ottolenghi, invented a new tool called the "pantopometro", capable of measuring all parts of the body.

In addition, subsequent to the early adoption of the Bertillon system, the Italian method was integrated and improved, through the introduction of not only fingerprints, but also detailed "anthropo-biographical cards" based on criminal anthropology. This was the birth of the "Ottolenghi method", completely inspired by Lombroso's theories. In short, the body, the psyche, and the past history of the criminal were included in an anthropo-biographical card, as elaborated by Ottolenghi and his followers. This realized one of Lombroso's dreams: the creation of a criminal law 
system, with its penitentiary laws focused not on the abstract offense, but on the "real" offender. Ottolenghi himself expressly dedicated his work to Lombroso, declaring that "our venerated and lamented Master [Lombroso had passed away, in 1909, one year before] had the fortune to see in the twilight of his life the long-cherished application of his doctrine, in the field [that of scientific policing] where the daily fight against crime is most fierce". ${ }^{72}$

The Ottolenghi method, established in 1902, was modified in 1914 to include more details about criminals' lives on the biographical cards, in line with the Lombrosian anthropological and psychological approach. In particular, sections related to criminals' biographical characteristics and moral and criminal attitudes (as a supplement to official notifications from the authorities) were added to the folders, with the specific aim of using these cards to more fully understand the person involved and "his body, his somatic constitution, his psyche, the way he thinks, the way he feels, [and] the way he wants". ${ }^{73}$

A substantial difference between the techniques used in other countries and the Italian method was the latter's comprehensive approach, assuming that fingerprints, measurements of body parts, and photographs alone were insufficient: the criminal's entire world was to be reconstructed from the identification folder. Simultaneously, the "Description and Identification Service" [Servizio di segnalamento e identificazione] was established to catalogue these folders. ${ }^{74}$

It is no coincidence that the Trattato di Polizia Scientifica [Treatise on Scientific Police], a monumental work in two volumes by Ottolenghi and containing all the fundamental techniques of forensic science, was dedicated not only to the physical and anatomical characteristics of offenders, such as parts of the body, hair and eye colour, and the shape of the skull, but also to "functional characteristics", such as physical activity, tics, and the tone of voice..$^{75}$ These elements of physical identification were described in the first volume; the second volume was primarily dedicated to the psychological biography of the offender as well as to judicial and forensic investigation. Mere physical identification was insufficient: psychic and biographical identification were also required in order to attain knowledge of the anthropological criminal. Among the biographical events noted were work experience, military service, and various habits (consumption of alcohol, contraction of disease, emigration) and sexual behaviour. Psychic identification included, for example, sensitivity and morality, as well as the detection of elements of these attributes, like posture and facial expressions. Identification of criminal slang adopted by criminals and the presence of tattoos on their bodies was thus emblematic in this context. The latter were not only physical, but also psychological, as stressed by Lombroso himself. ${ }^{76}$

\section{From criminal to enemy}

Despite the considerable progress in forensic science and policing made by Ottolenghi's School, his legacy is partly obscured by his involvement with the Fascist regime. Ottolenghi was a "fascist Jew" - an intellectual who, despite being Jewish, swore allegiance to the Fascist regime. We do not know if his allegiance was based on belief or, more presumably, opportunism; in any case, the School continued to operate under fascism, so we are able to consider the legacy of Lombroso under the regime. ${ }^{77}$ As is well-known, in 1925 the Consolidated Text of the Public Security Laws [Testo Unico delle 
leggi di pubblica sicurezza] was approved, as were the so-called "ultra-fascist laws" [leggi fascistissime] in 1925-1926. The latter aimed to expand the Central Political Registry [Casellario Politico Centrale] founded in 1894, which filed the details of political opponents and potential subversives. In a similar vein, in 1930, the regime approved the new penal code (Rocco Code, named after the fascist Minister of Justice, Alfredo Rocco), clearly designed as an instrument of repression. In other words, the dictatorship used every means to strengthen and protect itself. The scientific police and their tools could not be an exception to this process of fascistisation of all aspects of Italian society. Contributing to this was the fact that, after Ottolenghi's death, the next School director was Giuseppe Falco, one of Ottolenghi's pupils and another ardent fascist.

Prior to the advent of fascism, Ottolenghi pointed out that the purpose of scientific policing was to combat the frustrating phenomenon of recidivism and, more generally, to identify criminals who, having once committed a crime, had managed to escape justice. In 1910 he wrote about the benefits of description [segnalamento]: "the advantages will be immense in the field of identification [...] to recognize fingerprints, to reveal false identities, to track fugitives, to follow the steps of the most dangerous criminals". ${ }^{78}$

Nonetheless, with the advent of fascism, the scientific police became slowly but inexorably a deadly tool through which to control the regime's political opponents and enemies, as demonstrated by the numerous identification cards of socialists and communists, including that of Italian Communist Party leader, Palmiro Togliatti, identified in August 1926. Also of note is the 1937 identification card of Marxist activist Altiero Spinelli, which reflected his 1927 sentencing by the Special Tribunal for the Defence of the State, reportedly for "political reasons", and his subsequent exile to the islands of Ponza and Ventotene. Despite the underlying ideology of criminal anthropology (which is permeated by materialism and empiricism, when compared to fascist spiritualism) these Lombrosian theories became, contrary to expectations, an irreplaceable means to control all potentially dangerous people. Undeniably, as appropriately underlined by Mary Gibson, "what attracted fascist administrators to the anthropological-biographical dossier was not a dedication to science but the prospect of collecting vast amounts of data on a widening circle of individuals. Those convicted, or even suspected, of crimes could be labelled dangerous and kept under surveillance". 79

Criminal folders and other instruments developed and used by the scientific police were gradually employed less to fight crime and more to pre-classify potential political enemies. However, this author does not share Gibson's opinion that support from the School for fascist imperialism "flowed logically from the scientific racism of early positivists like Lombroso". ${ }^{80}$ The idea that racism was a crucial factor in Lombroso's work is a misconception that, thanks to the backing of leading scholars, still lingers today ${ }^{81}$ In fact, the concept of race had only a marginal role in Lombrosian criminal anthropology. Race was indeed much more relevant in the works of some of his more or less faithful pupils, such as Alfredo Niceforo. ${ }^{82}$

31 In the context of the difficult attempt to shift attention from the abstract study of criminal law to that of criminal man, with the aim to prevent crime, every factor, no matter how minor, had to be examined, from physical to psychic conformation, and including the social and geographical origin of the individual, according to Lombroso. 
Moreover, at that time, the role of race was undisputed by scientists, but Lombroso himself was of Jewish heritage and he had declared himself, albeit somewhat awkwardly, against the spread of anti-Semitism. ${ }^{83}$ On the contrary, the racism that slowly began to pervade Fascism occurred well after ${ }^{84}$ Lombroso's death, for several complex reasons (ranging from the spread of eugenics to political opportunism) ${ }^{85}$

Similarly, it is overly simplistic to see the authoritarian traces of the Rocco Code merely as a distortion of the positivist theories, when we should acknowledge that the Fascist regime itself was a complex and multi-faceted phenomenon. It is nevertheless true that many fundamental principles of the Positivist School (such as that of "social defence" or rather the need to protect society from crime by preventing it) were adopted and used by the Fascist regime for its own ends. The new penal code approved in 1930 took a peculiar shape, becoming a true and proper fascist criminal law, ${ }^{86}$ veering strongly towards extreme statism and authoritarianism that did not mesh at all with the principles of the Positivist School, ${ }^{87}$ especially its more progressive wing. ${ }^{88}$ Positivists were inspired by legal socialism, ${ }^{89}$ the "social question" and the aim of using legal science positively to transform society. ${ }^{90}$ Through direct study of the criminal and their world, Lombroso aimed to integrate law with real life, in order to establish an individualised system of punishment, rather than a moralist criminal law, which on the one hand used scientific theories to create easy "enemy" stereotypes, both internal and external, and on the other hand used Catholic principles to adopt a conservative and moralistic tone. ${ }^{91}$ It must not be forgotten that the intent of the Positivist School was to banish the belief that crime was a "sin" and that punishment represented "atonement", and to replace this approach with a criminological and sociological one. Despite the many ambiguities evident throughout Lombroso's work (for example, he was a socialist, yet at the same time favoured the death penalty in some cases), he probably would have preferred a society very different from that of the Fascist era, perhaps a secularised society in which science could be a means of liberation and human evolution. It suffices to recall Lombroso's criticism of the narrow-minded and chauvinist attitudes that subsequently became characteristic of the ideal Fascist man.

On the contrary, fascist criminal law as well as the "fascist police", liberally drawing on the "positivist galaxy", used positivistic weapons in a totally instrumental and antidemocratic way. ${ }^{92}$ For this reason it can be said that with the advent of Fascism, the Lombrosian legacy was dissipated, especially in the fields of law, policing, and criminal justice.

\section{The fascist method of identification}

Among the numerous areas affected by Lombroso's work, scientific policing is certainly one of the most significant. However, it should be noted that it would be wrong to consider simply that all the most negative aspects of the Fascist regime were derived from the application of Lombrosian theses (from racism to the regime's colonialism to the most repressive parts of the penal code). Indeed, fascist juridical culture took a completely different path following the ideals congenial to its politics, translating into the gradual elimination of individual rights. ${ }^{93}$

According to Mussolini's well-known motto, "all within the State, nothing outside the State, nothing against the State", one of the fundamental ideas of Fascism was the centrality of the State, and the legal reform undertaken by the Justice Minister Alfredo 
Rocco, with the support of his brother Arturo Rocco and other jurists, such as Vincenzo Manzini, was directed precisely towards strengthening this idea. Political violence, one of the key elements of the so-called Fascist revolution, was cunningly disguised as Fascist law. As Rocco himself stated, emphasising the need to spread the new Fascist spirit throughout the legal system, "the old law would be replaced by the new law: Fascist legality". ${ }^{94}$ In other words, the fascist legal system was based only apparently on the classical principle of nullum crimen sine lege, which was amended in the sense adopted by Fascist legal scholar Giuseppe Maggiore, who stressed that the Regime must consider as a crime not only every act violating a previous law but also every act offending the State's authority and deserving of punishment "according to the will of the Duce, sole interpreter of the will of the Italian people". ${ }^{95}$

For one thing, there was an increase in the quantity of categories of offences (the Special Part of the Rocco Code, dedicated to crimes and the related sanctions, was composed of 494 articles, whereas under the 1889 Zanardelli Code the equivalent part consisted of 395 articles). Moreover, the layout of chapters reflected the hierarchy of values to be protected. ${ }^{96}$ Not by chance, the first chapters addressed crimes against the personality of the State, public administration, public policy, and all other crimes that were related to the public sphere of the State. ${ }^{97}$

In this context it is clear that the scientific police and its affiliated techniques (from the development of fingerprinting to the improvement of identification using the biographical folders) were instrumental in the political violence of the regime. A decisive role in the fascistisation of the scientific police was undoubtedly played by Giuseppe Falco, representative of a group of post-Lombrosian scholars. To his medical training, Falco added the skills derived from criminal law lessons and criminology taught to him by Enrico Ferri, and began collaborating with Ottolenghi, up to his succession as director of the School in 1934.

To add to the body of knowledge of the study of criminal identification advocated by the School, in 1921 Falco published the first edition of his work "Identità". Metodo scientifico di segnalamento e identificazione ["Identity". Scientific Method of Description and Identification"] in which he analysed the biological methods of identification and description. Along the lines traced by Bertillon, Falco emphasized the importance of the guidelines of the School of Scientific Policing, which interpreted description [segnalamento] not only as an instrument useful to determine identity, but also as indispensable for attaining knowledge of the offender's personality. It was thanks to Falco's efforts that Ottolenghi's identification cards, created after the advent of the regime, were subsequently developed and expanded. In 1925, Falco faithfully devoted himself to both Lombrosian teachings and the Fascist regime, and developed new forms for insertion into the identification folders, extending them again after approval of the Rocco Code in 1930.

In the new folders, Falco's imprint is clearly quite congenial to fascist dictates and the new system of criminal law. The cards consisted of four parts: the "description" section [parte segnaletica] containing the general description; the "biographical" section [parte biografica], divided into two subsections - objective data (modus operandi, nature of the crime committed), and its psychic characteristics (emotion, intelligence, culture, idleness) in relation to the criminal's capacity [capacità a delinquere]; ${ }^{98}$ the "administrative-judiciary" section [parte giudiziaria-amministrativa], relating to information regarding the offender (criminal records, recidivism, application of 
security measures, inclination to crime); and finally, the "synthetic" section [parte sintetica], containing official judgements regarding the offender's social dangerousness and correctability. It is evident how this complex and articulated scheme reflected the so-called "double-track" system, ${ }^{99}$ adopted by the Rocco Code, which, in addition to traditional punishments, prescribed security measures, according to the level of social dangerousness of the offender, or rather, the judge's prediction about the possibility of their committing new crimes in the unknowable future. ${ }^{100}$

If it is true that Lombroso's Positivist School sought to replace the model of criminal law based on free will with one based on dangerousness, Fascism instead applied both criteria, thus producing an instrument capable of multiplying penalties. ${ }^{101}$ Once again the Fascist legislators had taken possession of and distorted the Lombrosian legacy. Moreover, at the behest of the Minister of Justice, Alfredo Rocco, in 1931 the School of Scientific Policing in Rome was transformed into the Criminal Museum [Museo Criminale], renamed in 1975 as the Criminological Museum [Museo Criminologico-MUCRI].

Furthermore, even the individuals subject to these measures had now changed: the "criminal tide" that Lombroso sought to address in the second half of the nineteenth century coincided substantially with the "dangerous classes" after Fascism's dramatic expansion and transformation: to the hardened criminals, idlers, and vagabonds were now added "subversives" and "political opponents" of the regime. Lombroso and Ferri's social defence concept was thus transformed by the regime into political violence against "the enemy". This is also evident from Falco's writings wherein he specified that the function of the biographical cards should be to support criminal justice, but above all to achieve a "general prophylaxis" and a "moral remediation" by extending the application of identification not only to criminals, but to anyone: "the biographical card, which contains the personality of the citizen[,] must be born, therefore, with the citizen himself, just as with every citizen their identity and civil status are born" ${ }^{102}$. In other words, anyone could be controlled and recorded by the regime according to the fascist motto "Distrust everything. Do not trust anybody! [Diffida di tutto. Non fidarti di nessuno!]"

\section{Conclusion}

This article has sought to trace the history of the birth and development of the scientific police in Italy and, from this, several conclusions can be drawn. First, despite its well-meaning intentions, Lombroso's criminal anthropology never succeeded in being completely neutral or merely an "exact science" uninfluenced by external social, political and social factors. A constant element that characterized Lombrosian theories and their use for the purposes of identification and control of crime wass their application against those who subverted the social and juridical order or who, in any case, were considered a danger to it. It was no coincidence that Lombrosian research on the born criminal began with the negative example of the brigand, an enemy of the Italian Risorgimento and anti-hero par excellence of united Italy.

After the violent repression of brigandage (even at the cost of giving up the legal guarantees of the juridical system of the Liberal era), ${ }^{103}$ at the end of the nineteenth century dangerous individuals gradually became those who lived on the edge of the metropolis: prostitutes, alcoholics, vagabonds, petty thieves, or rather all subjects characterising a type of urban crime that supplanted the rural one represented by 
rebels and brigands. Although during this period the first pioneering works appeared on organized crime, ${ }^{104}$ the times were not yet ripe to deal with complex but still inchoate phenomena such as mafia, "ndrangheta, camorra and other forms of organised crime [associazione al mal fare] ${ }^{105}$ interrelated with the old brigandage. ${ }^{106}$ Thus, the attention of the new-born criminology was still heavily focused on the dangerous individual, and their inability to choose freely between good and evil, and therefore on rejection of the concept of free will, and the consequent rejection of a criminal law based on this concept.

At the time of Lombroso's death and, above all, after the advent of the fascist regime, the "dangerous classes" changed again, now being composed not only of common criminals and prostitutes but especially of subversives, enemies of the regime, and political dissidents.

These are the three hypothetical phases of criminal anthropology applied to the control of crime and to the affirmation of the theory of social defence: the first that we could define as "foundational", in which the individual to be controlled was above all the brigand; the second phase at the "end of the century" coinciding with the advent of the dangerous classes (in the traditional sense) in Italy as elsewhere in Europe (subjects who came to live in the deprived urban neighbourhood of the cities); the third phase coinciding with the "fascistisation" of the Lombrosian theories or rather when the most dangerous subjects became the subversives and conspirators against the Fascist regime. It is true that even at the end of the nineteenth century the political offender, and in particular the anarchist, was studied by positivist criminologists but there was no real condemnation of this phenomenon. In this sense, Lombroso himself was quite condescending towards this category of criminal, defining political and anarchist offenders as human beings emotionally beyond normality [genî del sentimento] as they were affected by "political hysteria" and by a form of "altruism" that was so excessive that it amounted to a pathological condition. ${ }^{107}$

Not surprisingly, during these three phases the methods of study and identification of criminals used by the Scientific Police were also destined to suffer the same fate: despite the alleged neutrality of the techniques advocated by the School and by the Criminal Anthropology which it advocated, they became a means at the service of political power. While Lombroso's theories failed to influence the penal codes (especially the Zanardelli code of 1889), on the contrary his theories helped to criminalise the figure of the brigand, the primary objective of a policy that tried to silence the polemics about the difficult process of Italian unification that, according to the Southern population, was excessively imposed from above. In the same way, the registration of prostitutes, vagabonds, petty thieves, alcoholics and other deviant subjects, as well as the identification of every possible enemy of the fascist regime subsequently, was inevitably influenced by the shift in focus from crime to criminal proposed by the Positivist School. Lombrosian theories, as well as the Scientific Police inspired by them, thus became a sharp weapon, added to the arsenal of political violence in the hands of an authoritarian regime, to use at will against its opponents. In other words, an "enemy criminal law" was increasingly affirmed. ${ }^{108}$ Such a law could count on an apparatus, which became more and more technically advanced, in order to identify, control and catalogue each of the dictatorship's antagonists, even potential ones. 


\section{BIBLIOGRAPHY}

About, I., Les fondations d'un système national d'identification policière en France (1893-1914). Anthropométrie, signalements et fichiers, Genèses, 2004, 54, p. 28-52.

About, I., Naissance d'une science policière de l'identification en Italie (1902-1922), Les Cahiers de la Sécurité, 2005, 56, 1, p. 167-200.

About, I., Denis V., Histoire de l'identification des personnes, Paris, La Découverte, 2010.

Alessi, G., Lupi, volpi, selvaggi. Il paradigma del nemico tra eretici e anarchici, in Meccarelli, M., Palchetti, P., Sotis, C. (Eds.), Le regole dell'eccezione. Un dialogo interdisciplinare a partire dalla questione del terrorismo, Macerata, Eum, 2011, p. 103-125.

Alongi, G., La maffia nei suoi fattori e nelle sue manifestazioni: studio sulle classi pericolose della Sicilia, Torino, Bocca, 1887.

Anderson, M., In Thrall to Political Change. Police and Gendarmerie in France, Oxford-New York, Oxford University Press, 2011.

Crime, Histoire \& Sociétés / Crime, History \& Societies, vol. 22, n² | 2018 
Antonielli, L. (Ed.), La polizia in Italia e in Europa: punto sugli studi e prospettive di ricerca, Soveria Mannelli, Rubbettino, 2006.

Antonielli, L., Levati, S. (Eds.), Tra polizie e controllo del territorio: alla ricerca delle discontinuità, Soveria Mannelli, Rubbettino, 2017.

Baima Bollone, P., Cesare Lombroso ovvero il principio dell'irresponsabilità, Torino, SEI, 1992.

Beavan, C., Fingerprints: Murder and the Race to Uncover the Science of Identity, London, Fourth Estate, 2001.

Becker, P., Weak Bodies? Prostitutes and the Role of Gender in the Criminological Writings of 19th-Century German Detectives and Magistrates, Crime, Histoire \& Sociétés, 1999, 3, p. 45-69.

Becker, P., Wetzell, R.F. (Eds.), Criminals and Their Scientists. The History of Criminology in International Perspective, New York, Cambridge University Press, 2006.

Benigno, F., La mala setta. Alle origini di mafia e camorra 1859-1878, Torino, Einaudi, 2015.

Berger, E., Emsley, C., Police et ordre public en France et en Angleterre (1750-1850). Les perspectives de l'historiographie contemporaine, Crime, Histoire \& Sociétés, 2016, 20, [Online] http://journals.openedition.org/chs/1638.

Berlière, J.-M., Denys, C., Kalifa, D., Milliot, V. (Eds.), Métiers de police. Être policier en Europe, XVIII $X^{e}$ siècle, Rennes, Presses universitaires de Rennes, 2008.

Berlière, J.-M., Levy, R., Histoire des Polices en France, Paris, Nouveau Monde, 2013.

Bitonti, A., «Doppio binario» (entry), in Digesto delle discipline penalistiche, Torino, Utet, 2005, p. 393-414.

Bolis, G., La polizia e le classi pericolose della società. Studii, Bologna, Zanichelli, 1871.

Boudon, J.O. (Ed.), Police et gendarmerie dans l'Empire napoléonien, Paris, Éditions SPM, 2013.

Burgio, A., (Ed.), Nel nome della razza. Il razzismo nella storia d'Italia, 1870-1945, Bologna, Il Mulino, 1999.

Caplan, J., "One of the Strangest Relics of a Former State". Tattoos and the Discourses of Criminality in Europe, 1880-1920, in Becker, P., Wetzell, R.F. (Eds.), Criminals and Their Scientists. The History of Criminology in International Perspective, New York, Cambridge University Press, 2006, p. 337-361.

Caplan, J., Torpey, J. (Eds.), Documenting Individual Identity. The Development of State Practices in the Modern World, Princeton-Oxford, Princeton University Press, 2001.

Cappellini, P., Il fascismo invisibile. Una ipotesi di esperimento storiografico sui rapporti tra codificazione civile e regime, Quaderni fiorentini per la storia del pensiero giuridico moderno, 1999, 28, I, p. 175-282.

Cassata, F., "La difesa della razza". Politica, ideologia e immagine del razzismo fascista, Torino, Einaudi, 2008.

Centini, M., Il vampiro della Padania. Le indagini e il processo a Vincenzo Verzeni, lo «strangolatore di donne», Bergamo 1870, Torino, Ananke, 2009.

Chevalier, L., Classes laborieuses et classes dangereuses à Paris, pendant la première moitié du XIX siècle, Paris, Plon, 1958.

Churchill, D.C., Rethinking the State monopolisation thesis: the historiography of policing and criminal justice in nineteenth-century England, Crime, Histoire \& Sociétés, 2014, 18, p. 131-152. 
Colao, F., "Le scuole penalistiche” (entry), Enciclopedia Italiana di Scienze, Lettere ed Arti. VIII Supp. Diritto, Roma, Istituto dell'Enciclopedia Treccani, 2012, p. 349-356.

Colao, F., Neppi Modona G., Pelissero M., Alfredo Rocco e il codice penale fascista, Democrazia e Diritto, 2011, 1-2, p. 175-186.

Cole, S.A., Suspect Identities: a History of Fingerprinting and Criminal Identification, CambridgeLondon, Harvard University Press, 2001.

Corbin, A., L'hérédosyphilis ou l'impossible rédemption. Contribution à l'histoire de l'hérédité morbide [1981] in Id., Le Temps, le désir et l'horreur. Essais sur le XIX'e siècle, Paris, Flammarion, 2014.

Corbin, A., Les filles de noce. Misère sexuelle et prostitution (XIX ${ }^{e}$ et XX $X^{e}$ siècles), Paris, Aubier Montaigne, 1978.

Costa, P., "Classi pericolose" e "razze inferiori": la sovranità e la sue strategie di assoggettamento, I sentieri della ricerca. Rivista di storia contemporanea, 2008, 7-8, p. 333-351.

Davie, N., Tracing the Criminal: The Rise of Scientific Criminology in Britain, 1860-1918, Bardwell Press, Oxford, 2005.

Dezza, E., Le reazioni del positivismo penale al codice Rocco, Diritto penale XXI secolo, 2011, X, 2, p. 421-440.

Dunnage, J., Mussolini's Policemen: behaviour, ideology and institutional culture and representation and practice, Manchester, Manchester University Press, 2012.

Emsley, C., Crime, police, and penal policy. European experiences 1750-1940, Oxford, Oxford University Press, 2013.

Emsley, C., The Great British Bobby: A history of British policing from the eighteenth century to the present, London, Quercus, 2010.

Emsley, C., Gendarmes and the State in Nineteenth-Century Europe, Oxford, Oxford University Press, 1999.

Emsley, C., Shpayer-Makov, H. (Eds.), Police Detectives in History, 1750-1950, Hants-Burlington, Ashgate, 2006.

Falco, G., "Identità". Metodo scientifico di segnalamente e identificazione, Roma, Maglione \& Strini, 1923.

Falco, G., Cartella biografica, in Florian, E., Niceforo, A., Pende, N. (Eds.), Dizionario di Criminologia, Milano, Vallardi, 1943, vol. I, p. 126-126.

Ferrajoli, L., Diritto e ragione, Roma-Bari, Laterza, 2008.

Fijnaut, C., Criminology and the Criminal Justice System. A Historical and Transatlantic Introduction, Cambridge, Intersentia, 2017.

Finzi, R., Il pregiudizio. Ebrei e questione ebraica in Marx, Lombroso, Croce, Milano, Bompiani, 2011 [ebook version].

Fisher, T., Prostitution and the Victorians, New York, St. Martin's Press, 1997.

Fornari, U., Birkhoff, J., Serial Killer. Tre "mostri" infelici del passato a confronto, Torino, Centro Scientifico Editore, 1996.

Frégier, H.A., Des classes dangereuses de la population dans les grandes villes, et des moyens de les rendre meilleurs, Paris, Baillière, 1840, tt. I-II.

Frigessi, G., Cesare Lombroso, Torino, Einaudi, 2003. 
Garfinkel, P., Criminal Law in Liberal and Fascist Italy, Cambridge, Cambdrige University Press, 2017.

Gattei, G., Controllo di classi pericolose: la prima regolamentazione prostituzionale unitaria (1860-1888), in Betri, M.L, Gigli Marchetti, A. (Eds.), Salute e classi lavoratrici in Italia dall'Unità al Fascismo, Milano, FrancoAngeli, 2006, p. 764-796.

Gebhardt, H., Die Grazer Polizei 1786-1850: ein Beitrag zur Geschichte des österreichischen Sicherheitswesens im aufgeklärten Absolutismus und im Vormärz, Graz, Leykam, 1992.

Gibson, M., Born to Crime. Cesare Lombroso and the Origins of Biological Criminology, Westport, Praeger, 2002.

Gibson, M., Prostitution and the State in Italy, 1860-1915, London, Rutgers, 1986.

Gilardi, A., Wanted! Storia, tecnica ed estetica della fotografia segnaletica e giudiziaria, Milano, Bruno Mondadori, 2003.

Gould, S.J., The Mismeasure of Man, New York, Norton, 1981

Greco, G., Lo scienziato e la prostituta. Due secoli di studi sulla prostituzione, Bari, Dedalo, 1987.

Grossi, P., History of European Law, Malden, Wiley-Blackwell, 2010.

Gulotta, G., Breviario di psicologia investigativa, Milano, Giuffrè, 2008.

Higgs, E., Identifying the English. A History of Personal Identification 1500 to the Present, London-New York, Continuum, 2011.

Horn, D.G., The Criminal Body: Lombroso and the Anatomy of Deviance, New York-Abingdon, Routledge, 2003 [ebook version].

Hughes, S.C., Poliziotti, Carabinieri e "Policemens": il bobby inglesi nella polizia italiana, Le Carte e la Storia, 1996, 2, p. 22-31.

Jäger, J., Photography: A Means of Surveillance? Judicial Photography, 1850 to 1900, Crime, Histoire \& Sociétés, 2001, 5, p. 27-52.

Jayewardene, C.H.S., The English Precursors of Lombroso, British Journal of Criminology, 1963, 4, 2, p. 164-170.

Jessen, R., Polizei im Industrierervier Modernisierung und Herrschftepraxis im westfälischen Ruhrgebiet 1848-1914, Göttingen, Vandenhoeck \& Ruprecht, 1991.

Johansen, A., Lost in "Translation": The English policeman through a German monocle, 1848-1914, History, 2013, 98, p. 750-768.

Knepper, P., Johansen A., The Oxford Handbook of the History of Crime and Criminal Justice, Oxford, Oxford University Press, 2016.

Knepper, P., Ystehede, P.J. (Eds.), Cesare Lombroso Handbook, London, Routledge, 2013.

Lacché, L. (Ed.), Il diritto del duce. Giustizia e repressione nell'Italia fascista, Roma, Donzelli, 2015.

Lacché, L., Stronati M. (Eds.), Questione criminale e identità nazionale in Italia tra Otto e Novecento, Macerata, Eum, 2014.

Leschiutta, P., Palimsesti del carcere. Cesare Lombroso e le scritture proibite, Napoli, Liguori, 1996.

Leschiutta, P., Le pergamene viventi. Interpretazioni del tatuaggio nell'antropologia positiva italiana, La Ricerca Folklorica, 1993, 27, p. 129-138.

Leschiutta, P., Lombroso e i tatuaggi, in Montaldo, S. (Ed.), Il Museo di Antropologia criminale Cesare Lombroso dell'Università di Torino, Cinisello Balsamo, Silvana, 2015, p. 66-75. 
Lignereux, A., Servir Napoléon. Policiers et gendarmes dans les départements annexés, 1795-1814, Seyssel, Champ Vallon, 2012.

Lombroso, C., Esistenza di una fossa occipitale mediana nel cranio di un delinquente, Rendiconti del Reale Istituto Lombardo di Scienze e Lettere, 1871, s. II, vol. IV, I.

Lombroso, C., Della fossetta cerebellare mediana in un delinquente, Rendiconti del Reale Istituto Lombardo di Scienze e Lettere, 1872, vol. V, fasc. 18.

Lombroso, C., Sul tatuaggio in Italia, in ispecie fra i delinquenti, Archivio per l'antropologia e la etnologia, 1874, 4, p. 389-403.

Lombroso, C., L'uomo delinquente in rapporto all'antropologia, giurisprudenza e alle discipline carcerarie. Aggiuntavi la teoria della tutela penale del Prof. Avv. F. Poletti, Torino, Fratelli Bocca, $2^{\mathrm{e}}$ ed., 1878.

Lombroso, C., Sull'incremento del delitto in Italia e sui mezzi per arrestarlo, Torino, Fratelli Bocca, 1879 .

Lombroso, C., L'uomo delinquente in rapporto all'antropologia, giurisprudenza ed alle discipline carcerarie. Delinquente nato e pazzo morale, 3a ed. completamente rifatta, Torino, Fratelli Bocca, 1884.

Lombroso, C., Palimsesti del carcere. Raccolta unicamente destinata agli uomini di scienza, Torino, Fratelli Bocca, 1888 .

Lombroso, C., L'uomo delinquente in rapporto all'antropologia, alla giurisprudenza ed alle discipline carcerarie, Torino, Fratelli Bocca, 1889.

Lombroso, C., L'uomo delinquente in rapporto all'antropologia, alla giurisprudenza ed alle discipline carcerarie, Torino, Fratelli Bocca, vol. I, $5^{\mathrm{e}}$ ed., 1896.

Lombroso, C., L'uomo delinquente in rapporto all'antropologia, alla giurisprudenza ed alle discipline carcerarie. Atlante, Torino, Fratelli Bocca, 1897.

Lombroso, Discours d'ouverture au VI Congrès d'anthropologie criminelle, Comptes rendus du VI ${ }^{\mathrm{E}}$ Congrès international d'anthropologie criminelle, Turin, 28 avril-3 mai 1906, Torino, Fratelli Bocca, 1908.

Lombroso, C., Introduction, in Lombroso Ferrero, G. (Ed.), Criminal man, according to the classification of Cesare Lombroso, New York and London, G.P. Putnam's sons, 1911.

Lombroso, C., L'uomo delinquente [1878] now in Id., Delitto, genio, follia. Scritti scelti, Torino, Bollati Boringhieri, 2000.

Lombroso, C., Criminal Man, Durham-London, Duke University Press, 2006 [translated by Gibson, M. and Rafter, N.H.].

Lombroso, C., Laschi, R., Il delitto politico e le rivoluzioni in rapporto ad diritto, all'antropologia criminale ed alla scienza di governo, Torino, Bocca, 1890.

Lombroso Ferrero, G., Criminal Man According to Classification of Cesare Lombroso, New York, The Knickerbocker Press, 1911.

Luc, J-N. (Ed.), Gendarmerie, état et société au XIXe siècle, Paris, Publications de la Sorbonne, 2002.

Lucarelli, C., Picozzi, M., Serial killer. Storie di ossessione omicida, Milano, Mondadori, 2003.

Lüdtke, A., Police and State in Prussia, 1815-1850, Cambridge, Cambridge University Press, 1989.

Lupi, G., Serial killer italiani: cento anni di casi agghiaccianti da Vincenzo Verzeni a Donato Bilancia, Sesto Fiorentino (FI), Editoriale Olimpia, 2005. 
Maggiore, G., Diritto penale totalitario nello Stato totalitario, in Rivista italiana di diritto penale, 1939, 11, p. $140-161$.

Manna, A. (Ed.), Imputabilità e misure di sicurezza, Padova, Cedam, 2002.

Marchetti, P., L'armata del crimine. Teoria e repressione della recidiva in Italia. Una genealogia, Ancona, Cattedrale, 2008.

Marchetti, P., Le "sentinelle del male". L'invenzione ottocentesca del criminale nemico della società tra naturalismo giuridico e normativismo psichiatrico, Quaderni fiorentini per la storia del pensiero giuridico moderno, 2009, 38, II, p. 1009-1080.

Marchetti, P., Razza e criminalità. Un dibattito italiano di fine Ottocento, in Lacché, L., Stronati, M. (Eds.), Questione criminale e identità nazionale in Italia tra Otto e Novecento, Macerata, Eum, 2014, p. $127-140$.

Marchetti, P., La Scuola Positiva e i «nuovi orizzonti» del diritto penale tra pericolosità criminale e rischio sociale, Diritto penale XXI secolo, 2016, 2, p. 350-378.

Marques, T.P., Crime and the Fascist State, 1850-1940, London, Pickering \& Chatto, 2013.

Martini, A., Essere pericolosi. Giudizi soggettivi e misure personali, Torino, Giappichelli, 2018.

Mazzacane, A., La cultura giuridica del fascismo: una questione aperta, in Id. (Ed.), Diritto, economia e istituzioni nell'Italia fascista, Baden-Baden, Nomos, 2002, p. 1-15.

Milicia, M.T., Lombroso e il brigante. Storia di un cranio conteso, Roma, Salerno Editrice, 2014.

Milliot, V., Histoire des polices: l'ouverture d'un moment historiographique, Revue d'Histoire Moderne et Contemporaine, 2007, 2, p. 162-177.

Mori S., Tedoldi L. (Eds.), Forme e pratiche di polizia del territorio nell'Ottocento preunitario, Soveria Mannelli, Rubbettino, 2012.

Mosse, G.L., Toward the Final Solution. A History of European Racism, New York, Howard Ferting, 1978.

Musco, E., La misura di sicurezza detentiva. Profili storici e costituzionali, Milano, Giuffrè, 1978.

Musumeci, E., Le maschere della collezione «Lorenzo Tenchini», in Montaldo, S., Tappero, P. (Eds.), Il Museo di Antropologia criminale «Cesare Lombroso», Torino, Utet, 2009, p. 69-76.

Musumeci, E., Cesare Lombroso e le neuroscienze: un parricidio mancato. Devianza, libero arbitrio, imputabilità tra antiche chimere ed inediti scenari, Milano, FrancoAngeli, 2012.

Musumeci, E., New Natural Born Killers? The Legacy of Lombroso in Neuroscience and Law, in Knepper, P., Ystehede, Y. (Eds.), The Cesare Lombroso Handbook, London, Routledge, 2013, p. 131-146.

Musumeci, E., Emozioni, crimine, giustizia. Un'indagine storico-giuridica tra Otto e Novecento, Milano, FrancoAngeli, 2015a.

Musumeci, E., The Positivist School of Criminology and The Italian Fascist Criminal Law. A Squandered Legacy?, in Skinner, S. (Ed.), Fascism and Criminal Law: History, Theory, Continuity, Oxford-Portland, Hart, 2015b, p. 35-58.

Napoli, P., Naissance de la police moderne. Pouvoir, normes, société, Paris, La Découverte, 2003.

Oddone, V., Le origini della polizia scientifica, in Levra, U. (Ed.), La scienza e la colpa. Crimini criminali criminologi: un volto dell'Ottocento, Milano, Electa, 1985, p. 226.

Ottolenghi S., Trattato di polizia scientifica, Milano, Società editrice libraria, voll.1-2, 1910-1932. 
Ottolenghi, S., Ai lettori, in Bollettino della Scuola di Polizia Scientifica e del Servizio di Segnalamento, 1910,1, p. 3-4.

Penta, P., I pervertimenti sessuali nell'uomo e Vincenzo Verzeni strangolatore di donne: studio biologico, Napoli, Luigi Pierro, 1893.

Petrizzo, A., Pelli criminali? La scuola lombrosiana e il corpo tatuato a fine Ottocento, Contemporanea, 2016, 1, p. 43-68.

Piazza, P. (Ed.), Aux origines de la police scientifique. Alphonse Bertillon, précurseur de la science du crime, Paris, Karthala, 2011.

Piazza, P., Un œil sur le crime. Naissance de la police scientifique. Alphonse Bertillon de A à Z, Bayeux, OREP Éditions, 2016.

Pifferi, M., Reinventing punishment. A comparative history of criminology and penology in the nineteenth and twentieth centuries, Oxford, Oxford University Press, 2016.

Portigliatti Barbos, M., Le “pergamene viventi”: i tatuaggi, in Levra, U. (Ed.), La scienza e la colpa. Crimini criminali criminologi: un volto dell'Ottocento, Milano, Electa, 1985, p. 259-260.

Rafter, N., The Criminal Brain. Understanding Biological Theories of Crime, New York, New York University Press, 2008.

Renneville, M., Un cranio che fa luce? Il racconto della scoperta dell'atavismo criminale, in Montaldo, S., Tappero, P. (Eds.), Il Museo di Antropologia criminale, Torino, Utet, 2009, p.107-112.

Rhodes, H.T.F., Alphonse Bertillon, Father of Scientific Detection, Whitefish, Literary Licensing, 2013.

Rocco, A., Legge sulla facoltà del potere esecutivo di emanare norme giuridiche [1925], in Id. (Ed.), Discorsi parlamentari, Bologna, Il Mulino, 2005, p. 257.

Sbriccoli, M., Il diritto penale sociale, 1883-1912, in Id., Storia del diritto penale e della giustizia, Scritti editi e inediti (1972-2007), Milano, Giuffrè, 2009a, t. II, p. 819-902.

Sbriccoli, M., La commissione di inchiesta sul brigantaggio e la legge Pica, in Id., Storia del diritto penale e della giustizia, Storia del diritto penale e della giustizia. Scritti editi e inediti (1972-2007), Milano, Giuffrè, 2009b, t. I, p. 467-483.

Sbriccoli, M., Caratteri originari e tratti permanenti del sistema penale italiano (1860-1990), in Id., Storia del diritto penale e della giustizia, Storia del diritto penale e della giustizia. Scritti editi e inediti (1972-2007), Milano, Giuffrè, 2009c, t. I, p. 591-670.

Sbriccoli, M., La commissione di inchiesta sul brigantaggio e la legge Pica, in Id., Storia del diritto penale e della giustizia, Storia del diritto penale e della giustizia. Scritti editi e inediti (1972-2007), Milano, Giuffrè, 2009d, t. I, p. 467-483.

Self., H.J., Prostitution, Women and Misuse of the Law. The Fallen Daughters of Eve, London, Frank Cass, 2003.

Silei, G., Le radici dell'incertezza. Storia della paura tra Otto e Novecento, Lacaita, Roma, 2008.

Skinner, S. (Ed.), Fascism and Criminal Law: History, Theory, Continuity, Oxford-Portland, Hart, 2015

Stronati, M., Il brigante tra antropologia e ordine giuridico: alle origini di un'icona dell'uomo criminale nel XIX secolo, Quaderni fiorentini per la storia del pensiero giuridico moderno, 2009, t. II, p. 953-1008.

Turvey, B.E., Criminal Profiling: An Introduction to Behavioral Evidence Analysis, San Diego, Academic Press, 2011. 
Verga, G., Gramigna's Mistress, in Id., The She-Wolf and Other Stories, Berkeley-Los Angeles, University of California Press, 1973, p. 86-94 [original L'amante di Gramigna, in Vita dei campi: nuove novelle, Milano, Treves, 1880 , p. 153-171].

Villa, R., Il deviante e i suoi segni. Lombroso e la nascita dell'antropologia criminale, Milano, FrancoAngeli, 1985.

Villa, R., Sul processo di criminalizzazione della prostituzione nell'Ottocento, Movimento Operaio e Socialista, 1981, 3, p. 269-285.

Vronsky, P., Serial Killers: the method and madness of monsters, New York, Berkley/Penguin, 2004.

Walkowitz, J.R., Prostitution and Victorian Society. Women, Class and the State, Cambridge, Cambridge University Press, 1980.

Walsh, A., The Holy Trinity and the Legacy of the Italian School of Criminal Anthropology, Human Nature Review, 2003, 3, 1-11.

Zedner, L., Policing before and after the Police: the Historical Antecedents of Contemporary Crime Control, British Journal of Criminology, 2006, 46, 1, p. 78-96.

\section{NOTES}

1. L'Uomo Delinquente, first appearing in Italian in 1876, was not published in English until 1911, after Lombroso's death, when, thanks to the efforts of his daughter Gina, it appeared under the title of Criminal Man. See Lombroso Ferrero (1911).

2. Lombroso (1879, p. III).

3. On this concept in the Italian context, see Costa (2008).

4. On this literary trend see, for example, the "mysteries" books developed in many countries modelled on Les Mystères de Paris by Eugène Sue (1842), for example: Mysteries of London (1846), Los Misterios de Madrid (1844), Misteri di Napoli (1847), Misteri di Firenze (1854). See Silei (2008, p. 135-138) and Benigno (2015, p. VII-X).

5. On the use of animal metaphors in the description of those belonging to the "dangerous classes" (especially anarchists and other potential "subversives"), see Alessi (2011). Conversely, on the relevance of emotions and passions of anarchists and other political "criminals", see Musumeci (2015a, p. 130-143).

6. Bolis (1871, p. II).

7. At that time, this venereal disease became "loin de cristalliser l'anxiété que suscite alors l'hérédité morbide" (Corbin, 2014, p. 141) producing the anxiety that it could lead not only to a weakening of the sacred values of marriage and the family but above all, particularly at the end of the century, to biological and racial degeneration.

8. Gattei (2006); Greco (1987); Villa (1981) and Gibson (1986).

9. Sbriccoli (2009a, p. 894-895).

10. See Frégier (1840), who used the expression classes dangereuses for the first time, Chevalier (1958) and, more recently, Anderson (2011). More specifically, on the regulation of prostitution in France, see Corbin (1978).

11. For the relationship between prostitution and police in German-speaking countries in the XIX century see Becker (1999); for the English context, see Walkowitz (1980); Self (2003) and Fischer (1997).

12. On this topic, see Stronati (2009) and Sbriccoli (2009b, p. 467-483).

13. Lacché, Stronati (2014).

14. Stronati (2009, p. 957). 
15. Verga (1973, p. 93).

16. See Sbriccoli (2009c, p. 592-597).

17. On Bertillon and his system, see Piazza (2016); Piazza (2011); About (2004) and Rhodes (2013).

18. On the history of fingerprinting, see Cole (2001). For the history of personal identification (from the Middle Ages to the present day), see About, Denis (2010) and Caplan, Torpey (2001). More specifically, see Higgs (2011) for the English context, and About (2004) for the history of personal identification in France.

19. Lombroso (1879, p. 135).

20. See, for example, Ferrajoli (2008, p. 812).

21. Rafter (2008, p. 65).

22. Lombroso (1878, p. 50).

23. Lombroso (1896, v. I, p. 274-278).

24. On monstrosity in the works of Lombroso, see Musumeci (2009, p. 75-76).

25. Even though, according to Lombroso, this was a sort of "revelation" (Lombroso, 1911, p. XIV), the existence of this anomaly and its possible importance for understanding deviant behaviour was absolutely denied in the sciences.

26. Lombroso (1871, p. 41). Translation into English by David G. Horn (2003, p. 32).

27. Lombroso (2006, p. 48).

28. Lombroso Ferrero (1911 p. 15).

29. Lombroso (1872). On the discovery of Villella's fossetta, see especially Renneville (2009, p. 107-112).

30. Lombroso (1908, p. 6).

31. See Villa (1985, p. 144-149).

32. See Milicia (2014).

33. Obviously, Lombroso was not (and would not be in future) the only person to theorise the biological origins of crime, especially at a time when "biological theories and criminology were virtually synonymous" (Rafter 2008, p. XI); but he was definitely the most famous. Consider, for example, the British prison medical officers James Bruce Thomson and George Wilson, who theorized about the biological and hereditary nature of criminality before Lombroso, earning the appellation of "proto-Lombrosian". See Jayewardene (1963) and Davie (2005).

34. Baima Bollone (1992, p. 116).

35. Penta (1893).

36. Centini (2009).

37. The story of Verzeni, indeed, features in many specialized and popular texts, including: Lupi (2005, p. 45-50); Vronsky (2004, p. 58-61); Lucarelli, Picozzi (2003, p. 9-23); Fornari, Birkhoff (1996, p. 5-26).

38. Lombroso (1884, p. 587).

39. On the "deviant galaxy" retracable from Lombrosian research, see Musumeci (2012).

40. Lombroso (1888).

41. See Leschiutta (1996).

42. Lombroso (1888, p. 5).

43. Lombroso (2000, p. 436).

44. Other criminologists of the time studied the relationship between crime and tattoos. See Caplan (2006).

45. Lombroso (1874, p. 389-403).

46. Lombroso (1896, v. I, p. 341).

47. See Frigessi (2003, p. 107).

48. Lombroso (1889, p. 320).

49. See Leschiutta (1993); Portigliatti Barbos (1985). For more recent analysis, see Petrizzo (2016) and Leschiutta (2015). 
50. Horn (2003).

51. Lombroso (1897, Atlante, t. LXIV, f. 7).

52. Knepper, Ystehede (2013, p. 4).

53. See also Gibson (2002, p. IX).

54. Obviously the birth of criminology was not only an Italian prerogative but a phenomenon that involved almost all Western countries. For recent research on the history of criminology, including comparative perspectives, see Fijnaut (2017) and Knepper, Johansen (2016).

55. On the debate between the schools of criminal law in Italy, see Colao (2012).

56. On the polyvalent essence of the police and the history of the birth of the "modern" policing see Napoli (2003).

57. On the origins of modern policing and criminal investigation, see Emsley, Shpayer-Makov (2006); Zedner (2006) and Emsley (2013). On the history of policing in Europe, see Emsley (1999) and Berlière, Denys, Kalifa, Milliot (2008). More specifically, for the history of policing in France and Belgium see Berlière, Levy (2013); Boudon (2013); Lignereux (2012) and Denys (2013); for Great Britain, see Emsley (2010) and Churchill (2014); for Germany and Austria, see Jessen (1991); Lüdtke (1989) and Gebhardt (1992). In addition, for a comparative approach see Hughes (1996); Johansen (2013); Berger, Emsley (2016); Luc (2002) and Milliot (2007).

58. See About (2005, p. 168).

59. Moreover, according to Oddone (1985), the need for a scientific police also originated from the abolition of judicial torture as a way of arriving at the "truth" in criminal trials during the Ancien Régime.

60. For a comparative perspective on the relationship between science and crime, see Becker, Wetzell (2006).

61. On the concept of criminal dangerousness as "social risk", see Marchetti (2016). Conversely, for a recent perspective on social dangerousness, see Martini (2018).

62. See Antonielli, Levati (2017) and Mori, Tedoldi (2012).

63. Bolis (1871, p. 5).

64. Bolis (1871, p. 11).

65. Lombroso (1879, p. 135).

66. The famous battle of Sadowa in 1866 during the Austro-Prussian War determined the victory of Prussia thanks to excellent new military strategies and the massive use of modern firearms and new means of communication such as telegraph and teletype.

67. See Antonielli (2006).

68. Marchetti (2008).

69. On the history of fingerprinting, see Beavan (2001).

70. On the history of police photography used at the end of nineteenth century to control and detect criminals, see Jäger (2001).

71. See Gilardi (2003, p. 35-41).

72. Ottolenghi (1910, t. I, p. VII).

73. Falco (1943, p. 127).

74. Falco (1923, p. 3).

75. Ottolenghi (1910).

76. Lombroso (1874, p. 400-403).

77. Gibson (2002, p. 212).

78. Ottolenghi (1910, t. I, p. VIII).

79. Gibson (2002, p. 150).

80. Gibson (2002, p. 151).

81. It will suffice to recall the judgments expressed at the end of the 1970s by historian George Mosse, who mentioned Lombroso's born-criminal theory as the inspiration behind the Final Solution. See Mosse (1978) and, some years later, the American paleontologist Stephen Jay Gould, 
who blamed Lombroso for his pseudo-scientific theories, inception of racism and biological determinism. See Gould (1981).

82. On this topic, see Marchetti (2014).

83. Finzi (2011).

84. The real "racist turning point" of the Fascist regime was in 1938, with the publication of the Manifesto degli scienziati razzisti (Manifesto of Racist Scientists) in which the term "stock" [stirpe] was definitively replaced by that of "race" [razza]; the birth of the magazine La Difesa della Razza (The Defence of the Race); and the approval of the race laws that initiated the fascist persecution of Jews.

85. See Burgio (1999) and Cassata (2008).

86. On this topic, see especially Lacché (2015) and Skinner (2015). In addition, on the continuity between Liberal Italy and the Fascist regime, see Garfinkel (2017) and, for the influence on Italian penal reform of transnational criminological culture expressed at the International Congresses, see Marques (2013).

87. See Musumeci (2015b).

88. The Positivist School of Criminology was not a monolithic institution but rather a melting pot stemming from the different approaches of its three main founders, Cesare Lombroso, Raffaele Garofalo and Enrico Ferri, also defined as "the Holy Trinity" of the Positivist School (Walsh, 2003). For this reason, it is not possible to share Marques' opinion on the supposed independence of the Positivist School of Criminology from Lombrosian Criminal Anthropology as well as the idea that Lombroso's work, after his death, became only "a relic cherished by a somewhat eccentric family and a few disciples" (Marques, 2013, p. 43).

89. On this phenomenon, see Grossi (2010, p. 123-125).

90. Such an aim is clearly apparent from reading the titles of many works from scholars belonging to or affiliated with the Positivist School, such as La lotta di classe nella legislazione penale [The class struggle in criminal justice] (Adolfo Zerboglio), Ingiustizie sociali del codice penale [Social injustices in the criminal code] (Eugenio Florian), or Il delitto e la questione sociale [Crime and the social question] (Filippo Turati).

91. On the debate on the problem of individualisation of punishment, see Pifferi (2016).

92. On the fascistisation of police culture, see Dunnage (2012, p. 37-76).

93. See Mazzacane (2002) and, for the autonomy of juridical culture under Fascism, Cappellini (1999).

94. $\operatorname{Rocco}(2005$, p. 257).

95. Maggiore (1939, p. 160).

96. The provisions of the Code's special part were structured as follows: I Crimes against the Personality of the State; II Crimes against Public Administration; III Crimes against the Administration of Justice; IV Crimes against Religious Sentiment and against Piety to the Dead; V Crimes against Public Order; VI Crimes against Public Safety; VII Crimes against Public Faith; VIII Crimes against the Public Economy, Industry and Commerce; IX Crimes against Public Morality; X Crimes against the Integrity and Health of the Stock; XI Crimes against the Family; XII Crimes against the Person; XIII Crimes against Property.

97. See, for example, Colao et al. (2011, p. 184-185).

98. As stipulated by Article 133 of the Penal Code (relating to seriousness of the crime).

99. See, for example, Bitonti (2005).

100. See Manna (2002). On security measures and their comparative legal-historical analysis, see also Musco (1978).

101. Dezza (2011, p. 433).

102. Falco (1943, p. 129).

103. Sbriccoli (2009d, p. 467-483).

104. Alongi (1887). 
105. Lombroso (1896, I, p. 610).

106. On this topic, see Benigno (2015).

107. Lombroso, Laschi (1890, p. 342).

108. On the idea of criminal as an enemy between the nineteenth and twentieth centuries in Italy, see Marchetti (2009).

109. Ottolenghi (1910, p. 4).

110. See Gulotta (2008, p. 9-14).

111. See also Turvey (2011).

112. On the Lombrosian legacy in neuroscience and law debate, see especially Musumeci (2013, p. 131-146).

\section{ABSTRACTS}

This article analyses the impact of criminal anthropology, established by Cesare Lombroso, on the field of scientific policing in Italy. It focuses on the techniques and methods employed by police departments to identify and detect criminals and suspects at the end of the nineteenth century and during the first half of the twentieth century in order to control the so-called "dangerous classes". In Italy, the Bertillonage system was introduced thanks to the efforts of Salvatore Ottolenghi (1861-1934), a pupil of Cesare Lombroso and founder of the Italian scientific police (polizia scientifica). While such identification techniques spread to many countries, their deployment in Italy was different, being strongly influenced by Lombroso's concept of "criminal man". The so-called "Ottolenghi method" was used, particularly during the Fascist regime, to identify not only criminals but also "subversives", "enemies of social order" and any "suspicious person".

Cet article analyse l'impact de l'anthropologie criminelle de Cesare Lombroso dans le domaine de la police scientifique en Italie. Il met l'accent sur les techniques et les méthodes employées par les services de police pour identifier et détecter les criminels et les suspects à la fin du $\mathrm{XIX}^{\mathrm{e}}$ siècle. Pendant la première moitié $\mathrm{du} \mathrm{XX}^{\mathrm{e}}$ siècle, elles furent mobilisées afin de contrôler les « classes dangereuses ». En Italie, le système dit « de Bertillon » a été introduit grâce aux efforts de Salvatore Ottolenghi (1861-1934), élève de Cesare Lombroso et fondateur de la police scientifique italienne (polizia scientifica). Alors que ces techniques d'identification se sont répandues dans de nombreux pays, leur déploiement en Italie a été différent et fortement influencé par le concept d'«homme criminel» de Lombroso. La méthode dite «méthode Ottolenghi » a ainsi été utilisée, notamment sous le régime fasciste, pour identifier non seulement les criminels mais aussi les «subversifs », les « ennemis de l'ordre social » et toute «personne suspecte». 


\section{AUTHOR}

\section{EMILIA MUSUMECI}

Faculty of Law

University of Teramo

Emusumeci[at]unite.it 